\title{
CARBON FOOTPRINTS OF RUBBER PRODUCTS SUPPLY CHAINS (FRESH LATEX TO RUBBER GLOVE)
}

\author{
USUBHARATANA, P. - PhUNGRASSAMI, H.* \\ Excellence Center of EcoEnergy, Chemical Engineering Department, Faculty of Engineering, \\ Thammasat University \\ Pathumthani, Thailand \\ (phone: +66-2-564-3001; fax: +66-2-564-3010) \\ *Corresponding author \\ e-mail:pharnpon@engr.tu.ac.th \\ (Received $16^{\text {th }}$ Nov 2017; accepted $20^{\text {th }}$ Feb 2018)
}

\begin{abstract}
Carbon footprint emissions related to the natural latex supply chain including farm cultivation, concentrated latex production and rubber glove processing were investigated. Data were collected from 656 rubber plantations covering six provinces in the northeast, east, and south of Thailand and three concentrated latex production plants including one rubber glove processing factory. Different allocation methods were considered to compare the carbon footprint results including mass allocation, economic allocation and allocation by dry rubber content (DRC). Calculation methods were based on life cycle assessment (LCA) and ISO14067. Results indicated that farm size had no impact on the carbon footprint of fresh latex, with the carbon footprint of fertilizer application at planting estimated at more than $90 \%$ of the total contribution. For concentrated latex production, almost $70 \%$ of the carbon footprint originates from rubber cultivation. Total carbon footprint emission of 200 pieces of rubber glove was about $42 \mathrm{~kg}$ $\mathrm{CO} 2$-eq, allocated by mass during cultivation and by DRC in concentrated latex processing, with less than $1 \%$ from rubber plantations and concentrated latex processing. Allocation methods for the carbon footprint of rubber gloves do not affect the final result but have a great impact on the upstream process.
\end{abstract}

Keywords: allocation, concentrated latex, global warming, life cycle assessment, rubber glove

\section{Introduction}

Rubber products are derived from field latex collected from rubber trees. This field latex is converted into five primary forms as concentrated latex, air dried sheet, crepe rubber, Standard Thai Rubber (STR) and ribbed smoke sheet. These forms are used as raw material for manufacturing tires, rubber gloves, condoms, rubber hose and other rubber products. Ribbed smoke sheet and STR are usually used in the production of tires, while concentrated latex is used extensively for the manufacture of dipped products such as rubber gloves and condoms. Most rubber tree plantations are located in Southeast Asia and Thailand, Indonesia and Malaysia have suitable climates. In 2014, total global production of natural rubber was about 13 million tons. Data from the Food and Agricultural Organization of the United Nations (FAO) in 2014, showed Asia as the largest rubber producer (11.9 million tons) following by America and Africa with the same production (0.67 million tons) with the remainder from Oceania (FAOSTAT, 2017). In 2010, Thailand produced 3 million tons of rubber, accounting for $35 \%$ of the global output and this figure increased by $49 \%$ to 4.5 million tons in 2014 (FAOSTAT, 2017). However, Thai rubber output dropped in 2016 due to climate change and a sharp reduction in the rubber price. The climate fluctuation causes increasing annual rainfall (Ruangsri et al., 2015). Rainfall is a main climatic factor that influences on latex yield, an increase of rainfall can cause a loss of crop due to rainfall interference with tapping (Sdoodee and Rongsawat, 2012). Southern Thailand is a major rubber-producing area 
representing $70 \%$ of the country's total output which is decreasing. Around $15 \%$ of the total output is produced in northeast Thailand where production is expected to gradually increase as the government supporting rubber plantations in new areas (OAE, 2016a). Production of latex in Indonesia and Malaysia in 2014 was 3.1 million tons and 0.6 million tons respectively (FAOSTAT, 2017). All these countries are leading rubber producers; however, each has its own distinct manufacturing process. Malaysia and Indonesia focus on block rubber export, while Thailand exports concentrated latex and rubber sheet. The total value of concentrated latex in 2016 was 1,000 million USD with rubber sheet at 777 million USD (RIU, 2017). The total value of rubber gloves in 2014 was 1,105 million USD and $98 \%$ of production was exported (OIE, 2014). Thus, the industry is a key foreign exchange earner for Thailand.

Global industry and waste including wastewater greenhouse gas (GHG) emissions grew from $10.37 \mathrm{Gt} \mathrm{CO}_{2}$-eq in 1990 to $13.04 \mathrm{Gt} \mathrm{CO}_{2}$-eq in 2005 to $15.44 \mathrm{Gt} \mathrm{CO}_{2}$-eq in 2010 (Fischedick et al., 2014). Presently, increasing attempts to reduce environmental pollution and achieve the goal of sustainable agricultural products have focused on organic farming with synthetic fertilizer and pesticide reduction (Abeliotis et al., 2013). Limiting the use of nitrogen $(\mathrm{N})$ fertilizers will reduce $\mathrm{GHG}$ emissions which impact on global warming (Yan et al., 2015; Adewale et al., 2016). However, to achieve real sustainability, rubber cultivation supply chains and processing methods must all be considered to understand all aspects of the product life cycle.

The rubber industry is also monitored for environmental cleanliness. Rubber products exported to the international market require paperwork regarding sustainable production (Jawit et al., 2015). Rubber tree plantations impact on the environment through several steps, starting from land cultivation for seeding, preliminary treatment and use of pesticides and herbicides, including fertilizers (Phungrassami and Usubharatana, 2015). In the process of concentrated latex production, one environmental consideration is water pollution with the main sources of rubber wastewater as skim, latex or washing in various processes (Mohammad et al., 2010). During the final production process, fuel-wood (old rubber-wood) combustion in burners without proper pollution control devices may cause high contamination from smoke in the workplace (Choosong et al., 2010).

Interest in environmental issues has risen significantly over the past decades, and the Thai Government and business owners have become aware of pollution impacts on global warming . Thailand launched the National Master Plan on Climate Change (20102019) to increase pollution awareness by the population (Kabiri, 2016). The Thailand Climate Change Master Plan was also recently implemented (2012-2050) with the objectives to improve economics, society and the environment, and cut GHG emissions by 2050 without impeding the country's gross domestic products.

Global GHG emissions generated from industry are comprised of direct energy ity and heat of emissions from production of electric ${ }_{2}$ indirect $\mathrm{CO}$,emission ${ }_{2}$ related $\mathrm{CO}$ emissions 2 precesss $\mathrm{CO}$,industry, non $\mathrm{CO}_{2}$ GHG emissions and direct emissions for waste or wastewater (Fischedick et al., 2014). All the stages in the manufacturing processes of rubber products, it consumes a high quantity of energy, water and other natural resources (Dayaratne and Gunawardana, 2015). Therefore, an environmental baseline survey is necessary to establish policy and action plans to reduce GHG emissions. The assessment tool for the relative impact of production systems occurring throughout the whole product life cycle is life cycle assessment (LCA) (Sparrevik et al., 2015). Both input and output data in a selected system boundary of a product are 
evaluated by environmental impact assessment throughout their entire life cycle. Setting LCA objectives has an influence on delimitation and result of assessment. Several LCA studies focused on the ecological footprints of ribbed smoked sheet (RSS), ribbed smoked sheet bale (RSSB) and concentrated latex (Musikavong and Sheewala, 2017). Phungrassami and Usubharatana (2015) collected data on planting rubber trees and assessed the environmental impacts of rubber wood production in Thailand. Dayaratne and Gunawardana (2015) studied carbon footprint (CF) emissions from small and medium enterprises (SMEs) manufacturing rubber bands in Sri Lanka with a focus on energy-efficiency but did not refer to the primary products such as the carbon footprints of fresh latex and concentrated latex. Maulina et al. (2015) applied the LCA and ecoefficiency to investigate the environmental impact of crumb rubber. Lin et al. (2017) studied the LCA of rubber tires with the aim of reducing their carbon footprint by replacing carbon black with graphene. Jawjit et al. (2015) conducted a life cycle assessment of concentrated latex production in Thailand; however, the scope of their study followed a gate-to-gate approach considering concentrated latex processing only, not the upstream processes which occurred at the rubber plantation. Jawjit et al (2010) assessed GHG emissions from concentrated latex, block rubber (STR20) and the RSS sector in the rubber industry. Their results indicated that GHG emissions from fresh latex amounted to 0.2 tons $\mathrm{CO}_{2}$-eq/ton fresh latex (excluding land conversion) and 144 $\mathrm{kg} \mathrm{CO}$-eq/ton concentrated latex (considering only gate-to-gate factory). However, their paper contained no reference to the allocation of fresh latex and rubber wood which are joint-products of rubber plantations. Ounsaneha and Rattanapan (2016) studied the eco-efficiency of rubber gloves. The scope of their study was limited to a gate-to-gate approach to define the performance and environmental hotspots of the process. Results revealed that electricity usage and chemical consumption were the most significant environmental problems; however, life cycle assessment was not applied.

From the literature reviews, a full analysis of rubber glove production starting from the rubber plantation through to glove processing has rarely been reported, with most authors adopting only a gate-to-gate approach. Limited information exists regarding the carbon footprint emission allocation of the rubber supply chain.

An environmental impact assessment of products in this study focused on the CF of manufacturing rubber products such as concentrated latex as an intermediate product and rubber gloves as the final product. The $\mathrm{CF}$ was used to develop an environmental inventory and impact assessment based on life cycle methodology for three products as fresh latex, concentrated rubber and rubber gloves. The specific objectives were to (1) establish an inventory for CF analysis of selected products, (2) assess the CF of different farm sizes through to rubber gloves manufacture, (3) identify environmental hotspots in the selected product system boundary, and (4) consider rubber products allocation. Results will be beneficial for environmentally concerned, policy makers and other primary rubber product users who form the majority of Thailand's rubber product exports.

This paper begins with an introduction, background and rationale. Section 2 describes the principles and framework for life cycle assessment (LCA) including planting rubber trees, processing field latex into concentrated latex, and producing rubber gloves. Section 3 discusses the results of the assessment by testing three areas as GHG emissions from plantations and GHG emissions from concentrated latex production and rubber glove manufacturing. Conclusions are drawn in section 4 . 


\section{Materials and methods}

There is potential to decrease the global warming effect of primary rubber production through to the final product. Policy-makers and environmentally concerned customers must understand the importance of conducting CF assessments to collect benchmark information. The $\mathrm{CF}$ of the whole process from planting rubber trees to processing concentrated latex and manufacturing rubber gloves was investigates. A cradle to grave approach was followed to estimate GHG emissions associated with material inputs, energy, and activities during the product chain within the product system boundary. The method for LCA consideration was based on ISO14040 (2006) including ISO/TS14067 (2013) guidelines consisting of four steps as (1) goal and scope definition, (2) inventory analysis, (3) impact assessment and (4) interpretation.

\section{Goal and scope}

The goal and scope definition provides the goal of the study and description of the product system, including the functional unit and system boundary (Wang et al., 2010). The goal of the study defined the life cycle inventory and CF of two different rubber products manufactured in Thailand as latex primary product (concentrated latex) and the final product (rubber gloves); planting details were also considered. Moreover, environmental hotspots of selected products in each system boundary were identified and analyzed. The functional unit and system boundary settings were defined and related data were provided. In addition, the co-product allocations in the life cycle assessments of plantations as field latex, rubber waste and rubber wood were assessed.

A functional unit is defined and used to establish a basis for comparison of alternative products or services (ISO14044, 2006). Meier et al. (2015) examined the LCA of agricultural products and determined that most authors defined functional unit per product unit in accordance with Jawjit et al. (2010) as the default unit of weight. The functional unit in the agricultural sector can be defined by both area (expressing the intensity of the production system) and product (quantitative measure of efficiency) (Holka et al., 2016). Three processes were identified as rubber tree cultivation, processing concentrated latex and manufacturing rubber gloves. Therefore, the functional unit was set in terms of mass of fresh latex $\left(\mathrm{g} \mathrm{CO}_{2}-\mathrm{eq} / \mathrm{kg}\right.$ fresh latex), mass of concentrated latex ( $\mathrm{kg} \mathrm{CO}_{2}$-eq/ton concentrated latex) and a box of rubber gloves $(\mathrm{kg}$ $\mathrm{CO}_{2}$-eq/200 pieces size L weight $56 \mathrm{~g}$ per two pieces).

The system boundary for carbon footprint assessment of selected products manufactured in Thailand was considered as "cradle to farm gate" for rubber tree cultivation, "cradle to factory gate" for concentrated latex and "cradle to grave" for rubber gloves (Fig. 1).

The first process analyzed was rubber tree cultivation. The system boundaries included inputs and emissions, i.e. fertilizers and emissions due to use of $\mathrm{N}$-fertilizer, diesel and GHG emissions due to fuel combustion, with pesticides also taken into account. However, impacts due to the life cycle of equipment and other infrastructure were not considered. The second process related to concentrated latex processing. All energy consumption used in production including electricity and diesel, utilities such as water and chemicals and especially preservatives for natural rubber latex were considered. The third process was rubber glove processing which considered and water consumption including several chemicals. Disposal of wastes as discarded gloves and packaging was also taken into account. 


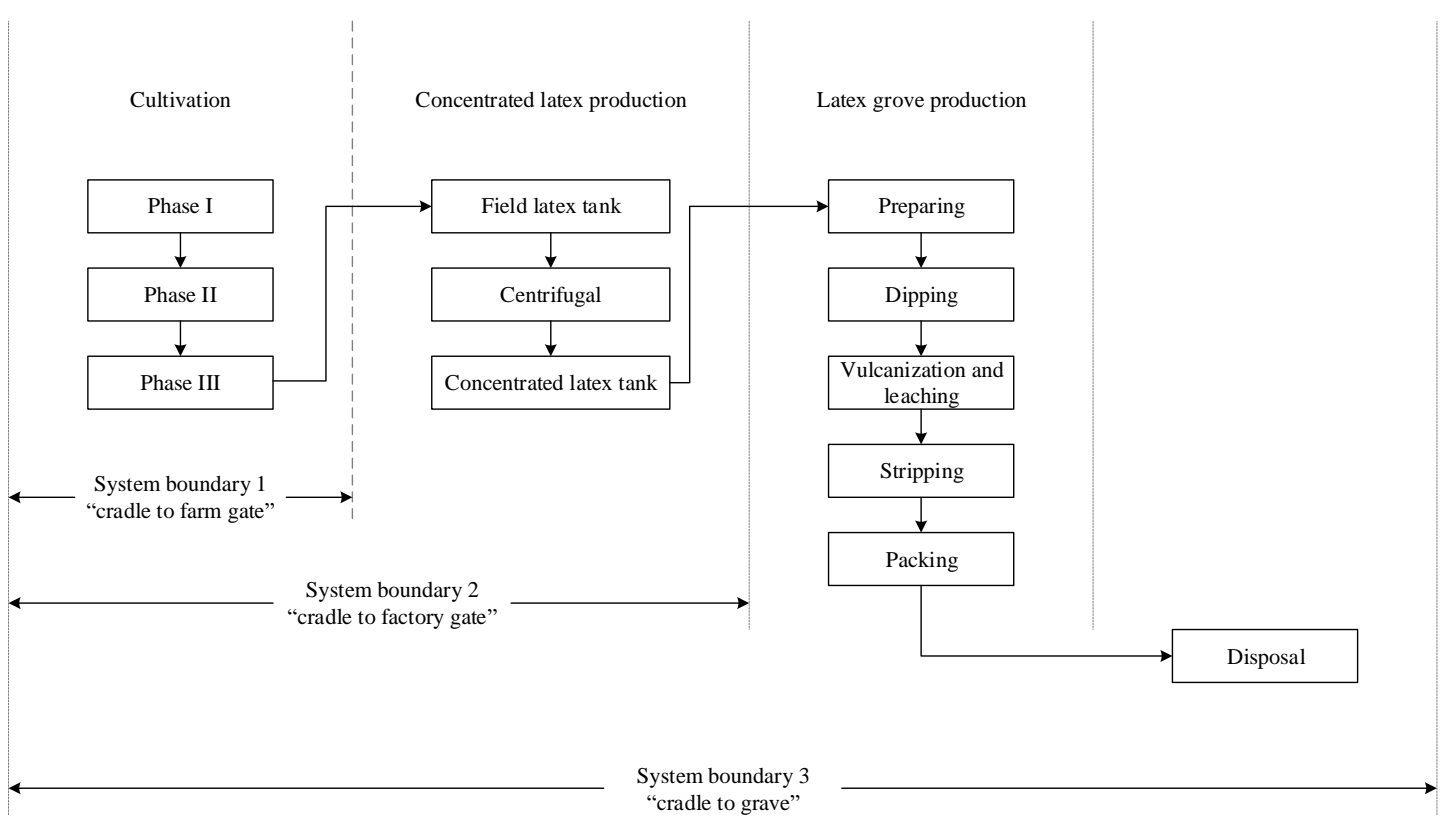

Figure 1. System boundary for the carbon footprint of selected products $i$ at each level

\section{Life cycle inventory}

\section{Cultivation}

For the period of 2014-2016, a simple random sample of 656 farmers was conducted in six Thai Provinces including Chanthaburi, Rayong, Bueng Kan, Udon Thani, Nakhon Si Thammarat and Surat Thani. Bueng Kan and Udon Thani located in the northeast which is the highland area. Both two provinces are considered as the new area of rubber plantation. Chanthaburi and Rayong located in the east which is near the coast. The rest provinces located in the southern part of Thailand which also is near the coast. Rubber tree plantations in Thailand are divided based on size into three types as small-sized farms (less than $8 \mathrm{ha}$ ), medium-sized farms (8-40 ha) and large-sized farms (more than 40 ha) (Rubber Replanting Aid Fund Act, 1960). The planting process is divided into three major phases; preparing and cultivating the area, growing and maintaining rubber trees before the tapping period (1-8 years) and maintaining rubber trees during the tapping period (9-25 years). For phrase I, the amount of diesel and fertilizer as 3-6-8, 15-15-15 or 0-3-0 (N-P-K ratio) are used for land preparation based on the needs. In phase II, both organic and chemical fertilizer as 18-8-8, 15-15-15, 20-8-20, 25-7-7 are added to the soil. Sometimes, glyphosate or paraquat herbicides are also added. In phrase III, large amounts of fertilizer in different formulas as 16-8-8, 15-15-15, 15-7-18, 25-7-7 are required. Chemical fertilizers used in the GHG emission assessment were defined as nitrogen $(\mathrm{N}), \mathrm{P}_{2} \mathrm{O}_{5}$ and $\mathrm{K}_{2} \mathrm{O}$ equivalent. The products were classified into three main groups as fresh rubber, rubber residue and para-rubber wood. Although ISO14044 (2006) suggests avoiding the allocation, the products become the raw materials for concentrated latex, Thai standard rubber and rubber wood furniture. Therefore, mass allocation of environmental burdens was conducted for each product with allocation ratios as para-rubber wood $63.48 \%$, fresh latex $35.65 \%$ and rubber residue $0.87 \%$ (Phungrassami and Usubharatana, 2015). 


\section{Concentrated latex production}

Fresh latex obtained on tapping has about 30-35\% dry rubber content (DRC) with the remainder as non-rubber solids and water which is delivered for concentration to the latex factory. The definition of concentrated latex is a liquid containing at least $60 \%$ DRC. Different methods are used to concentrate the including evaporation using heat to remove the water with the product called evaporation latex, creaming by adding a creaming agent when the product is called creamed latex, or a centrifugal method with the product called centrifuged latex. The centrifugal method is used in most concentrated latex factories in Thailand. The stability of fresh latex is preserved and enhanced by adding ammonia and TMTD/ZnO (tetramethyl thiuram disulfide/zinc oxide) and then it is passed through a sieve into the gutter and kept suitable for spinning by adding ammonia (>4\%). For fresh latex with high magnesium content, diammonium hydrogen phosphate (DAP) is added to precipitate the magnesium. Thereafter, the fresh latex is placed into a high speed Centrifuge Separator Machine to remove the water. A $60 \%$ concentrated latex and skim latex are obtained using this process. Preservatives are added to supplement the concentrated latex. High Ammonia (HA) latex is preserved with $0.7 \%$ wt. ammonia and Low Ammonia (LA) latex concentrate is preserved with $0.2 \% \mathrm{wt}$ ammonia. For skim latex containing less than $8 \%$ rubber content, $\mathrm{NH}_{3}$ is released to air, $\mathrm{H}_{2} \mathrm{SO}_{4}$ is added and its form is changed into coagulum, crepe, and finally into crumbs.

\section{Rubber glove production}

The raw materials for rubber glove production are concentrated latex $60 \% \mathrm{DRC}$ and a chemical latex stabilizer like potassium hydroxyl, including a chemical vulcanizing system like zinc oxide $(\mathrm{ZnO})$. The concentrated latex is mixed with various compounding chemicals based on need, then brought to forming process with dipping technique, which is the main production process followed by Thailand's rubber glove manufacturers (Ounsaneha and Rattanapan, 2016). In this process, a mold is dipped in a cleaning tank which has three steps as acid clean the tank to remove mold residues, water rinse the tank to remove the acid from the previous step and alkali clean the tank to dissolve proteins and fats. Then, the mold is dipped in a tank containing calcium nitrate and calcium carbonate as a coagulant. Next, the mold is dipped into a latex dipping tank at high temperature to enhance the coagulation efficiency of the latex and to easily roll the edges of the rubber gloves. Then, the rubber gloves with the rolled edges are re-heated until vulcanization and the mold is removed. The gloves are then dried with liquid petroleum gas (LPG). The final process consists of inspection and finishing.

\section{Impact assessment}

This stage consists of classification, characterization (mandatory phase) and normalization, weighting (option phases) (ISO14040, 2006). Only mandatory phases were conducted in this study. The effect of global warming was taken as mid-point characterization factors and calculated using the International Panel of Climate Change (IPCC) methodology following AR4 (Solomon et al., 2007). Global warming potential (GWP) activities in the system boundary were estimated from Equation 1: 


$$
C F=\sum_{i=1}^{n} A_{i} \times E F_{i}
$$

where CF represents the total of the GHG emissions from all activities in the system boundary in $\mathrm{kg} \mathrm{CO}$-eq, A represents the $\mathrm{i}^{\text {th }}$ activity data presented in the form of amount of environmental load such as electricity in $\mathrm{kWh}$, diesel in $\mathrm{kg}$, chemicals in $\mathrm{kg}$, and $\mathrm{EF}_{\mathrm{i}}$ is the GHG emission factor of the $\mathrm{i}^{\mathrm{t}}$ input in $\mathrm{kg} \mathrm{CO}_{2}$-eq/unit such as electricity in $\mathrm{kg} \mathrm{CO} \mathrm{CO}_{2}$-eq/kWh. The main database used was Ecoinvent (2010) in the libraries of Simapro where materials or energy for production of one unit of a product is stored . However, in the case that materials or energy production were available in Thailand, the database managed by National Metal and Materials Techonology Center, Thailand (2014) was used to reflect the actual results.

In the case of planting, direct $\mathrm{N}_{2} \mathrm{O}$ emissions from $\mathrm{N}$ fertilizer utilization were estimated from Equation 2:

$$
C F_{N 2 O}=A_{F} \times 0.01 \times \frac{44}{28} \times 298
$$

where $\mathrm{CF}_{\mathrm{N} 2 \mathrm{O}}$ represents the direct $\mathrm{N}_{2} \mathrm{O}$ emissions converted to $\mathrm{CO}_{2}$ equivalent from application of $\mathrm{N}$-fertilizer in $\mathrm{kg} \mathrm{CO}_{2}$-eq, $\mathrm{A}_{\mathrm{F}}$ is the amount of $\mathrm{N}$-fertilizer applied in the cultivation process in $\mathrm{kg} \mathrm{N}$-fertilizer, 0.01 is the emission factor for $\mathrm{N}_{2} \mathrm{O}$ from $\mathrm{N}$ inputs, $\mathrm{kg} \mathrm{N}_{2} \mathrm{O}-\mathrm{N}$ (kg N input) ${ }^{-1}, 44 / 28$ is the conversion factor of $\mathrm{N}_{2}$ to $\mathrm{N}_{2} \mathrm{O}$, and 298 is the relative potential of global warming in a 100-year horizon (Solomon et al., 2007). Therefore, output units for the selected products $\mathrm{CF}$ are $\mathrm{kg} \mathrm{CO}$-eq $/ \mathrm{kg}$ product or ton of product.

\section{Allocation scenario analysis}

Further analysis of allocation methods for the CF results of the product chain was applied using hypothetical simulations. Base case assessment considered the allocation method and mass allocation was applied in planting with DRC allocation applied in concentrated latex production. Three groups of scenarios were modeled. Each model altered when comparing the base case scenarios of rubber glove' life cycle to estimate the overall environmental impact of rubber glove. The scenarios were split into multiple parts as scenario 1 which considered economic allocation in planting and DRC allocation in concentrated latex production. Scenario 2 considered mass allocation in both planting and DRC allocation in concentrated latex production and scenario 3 considered economic allocation in planting and mass allocation in concentrated latex production.

\section{Results and discussion}

\section{Greenhouse gas emissions at plantation}

A survey of Thai rubber farmers during 2014-2016 gave 381 small farmers (total area 819 ha), 253 medium farmers (total area 2,512 ha) and 22 large farmers (total area 1,007 ha) accounting for $0.14 \%$ of the total rubber wood plantation area in Thailand (total Thai plantation area was $3,138,169$ ha in 2016). Most of surveyed farmers 
cultivated clone RRIM600 which is highly susceptive to diseases and economic incentive to develop new rubber tree clones (Pethin et al., 2015). Details of the plantations are shown in Table 1. Small farms accounted for 19\%, medium farms $58 \%$ and large farms $23 \%$ of the total cultivated area. The amount of fresh latex varied with farm size; however, overall yield was $1,725-3,193.75 \mathrm{~kg} / \mathrm{ha}$ (a factor of 2). In addition, results revealed that farm size did not reflect yield performance management, and a large farm could have less yield than a small farm. However, larger farms had higher weighted average yields, except in Nakhon Si Thammarat where the weighted average yield of medium farms was lower than small farms. Thailand's weighted average yield in 2016 was 1,500 kg/ha (OAE, 2016b).

Table 1. Some characteristics of rubber plantation

\begin{tabular}{|c|c|c|c|c|c|c|}
\hline \multirow[t]{2}{*}{ Farm characteristics } & \multicolumn{3}{|c|}{$\begin{array}{l}\text { Chanthaburi } \\
\text { Farm size }\end{array}$} & \multicolumn{3}{|c|}{$\begin{array}{l}\text { Rayong } \\
\text { Farm size }\end{array}$} \\
\hline & Small & Medium & Large & Small & Medium & Large \\
\hline $\begin{array}{l}\text { No. of farms } \\
\text { Total area (ha) } \\
\text { Yield }(\mathrm{kg} / \mathrm{ha} / \mathrm{y})\end{array}$ & $\begin{array}{c}60 \\
128\end{array}$ & $\begin{array}{c}30 \\
286\end{array}$ & $\begin{array}{c}2 \\
88\end{array}$ & $\begin{array}{c}61 \\
134\end{array}$ & $\begin{array}{c}32 \\
321\end{array}$ & $\begin{array}{c}1 \\
43\end{array}$ \\
\hline - Range & $1,125-3,750$ & $1,325-3,494$ & $2,588-3,000$ & $1,056-3,831$ & $1,275-3,581$ & 3,194 \\
\hline $\begin{array}{l}\text { - Weighted average } \\
\text { Diesel (kg/ha) }\end{array}$ & 2,038 & 2,456 & 2,775 & 2,375 & 2,413 & 3,194 \\
\hline - Range & $0-16$ & $0-16$ & 16 & $0-16$ & $0-16$ & 16 \\
\hline $\begin{array}{l}\text { - Weighted average } \\
\text { Synthetic fertilizer }(\mathrm{ha} / \mathrm{kg})\end{array}$ & 10 & 10 & 16 & 15 & 15 & 16 \\
\hline - Range & $938-28,688$ & $2,250-31,563$ & $10,544-13,500$ & $0-24,125$ & $2,500-19,063$ & 13,750 \\
\hline $\begin{array}{l}\text { - Weighted average } \\
\text { Organic fertilizer (ha/kg) }\end{array}$ & 13,219 & 14,631 & 11,888 & 11,163 & 11,763 & 13,750 \\
\hline - Range & $0-46,875$ & $0-33,075$ & 0 & $0-45,000$ & $0-31,875$ & 0 \\
\hline - Weighted average & 3,031 & 5,750 & 0 & 6,856 & 2,575 & 0 \\
\hline Chemicals (ha/kg) & & & & & & \\
\hline - Range & $0-469$ & $0-625$ & 313 & $0-750$ & $0-438$ & 269 \\
\hline - Weighted average & 138 & 156 & 313 & 106 & 106 & 269 \\
\hline \multirow[t]{2}{*}{ Farm characteristics } & \multicolumn{3}{|c|}{$\begin{array}{l}\text { Bueng Kan } \\
\text { Farm size }\end{array}$} & \multicolumn{3}{|c|}{$\begin{array}{l}\text { Udon Thani } \\
\text { Farm size }\end{array}$} \\
\hline & Small & Medium & Large & Small & Medium & Large \\
\hline No .of farms & 53 & 30 & 1 & 61 & 29 & 2 \\
\hline $\begin{array}{l}\text { Total area (ha) } \\
\text { Yield }(\mathrm{y} / \mathrm{ha} / \mathrm{kg})\end{array}$ & 101 & 289 & 64 & 170 & 261 & 96 \\
\hline - Range & $900-2,769$ & $1,350-3,038$ & 2,700 & $781-2,406$ & $1,125-3,038$ & 2,113 \\
\hline $\begin{array}{l}\text { - Weighted average } \\
\text { Diesel (ha/kg) }\end{array}$ & 1,850 & 2,013 & 2,700 & 1,725 & 2,031 & 2,113 \\
\hline - Range & 23 & 23 & 31 & 23 & 23 & 31 \\
\hline $\begin{array}{l}\text { - Weighted average } \\
\text { Synthetic fertilizer }(\mathrm{kg} / \mathrm{ha})\end{array}$ & 23 & 23 & 31 & 23 & 23 & 31 \\
\hline - Range & $2,344-28,500$ & $7,875-42,563$ & 18,256 & $1,688-34,719$ & $13,281-34,094$ & $19,844-21,388$ \\
\hline $\begin{array}{l}\text { - Weighted average } \\
\text { Organic fertilizer (kg/ha) }\end{array}$ & 14,588 & 16,438 & 18,256 & 16,713 & 23,844 & 20,619 \\
\hline - Range & $0-47,500$ & $0-106,250$ & 37,150 & $0-56,406$ & $0-17,813$ & 0 \\
\hline - Weighted average & 3,319 & 4,700 & 37,150 & 3,538 & 1,531 & 0 \\
\hline Chemicals (kg/ha) & & & & & & \\
\hline - Range & $0-194$ & $0-194$ & 156 & $0-469$ & $0-625$ & 313 \\
\hline - Weighted average & 69 & 63 & 156 & 138 & 156 & 313 \\
\hline
\end{tabular}




\begin{tabular}{|c|c|c|c|c|c|c|}
\hline \multirow[t]{2}{*}{ Farm characteristics } & \multicolumn{3}{|c|}{$\begin{array}{c}\text { Nakhon Si Thammarat } \\
\text { Farm size }\end{array}$} & \multicolumn{3}{|c|}{$\begin{array}{l}\text { Suratthani } \\
\text { Farm size }\end{array}$} \\
\hline & Small & Medium & Large & Small & Medium & Large \\
\hline No .of farms & 75 & 56 & 5 & 71 & 76 & 11 \\
\hline Total area (ah) & 140 & 565 & 242 & 146 & 791 & 472 \\
\hline \multicolumn{7}{|l|}{ Yield (y/ha/kg) } \\
\hline - Range & $700-3,450$ & $344-3,781$ & $1,538-2,963$ & $531-4,831$ & $613-4,331$ & $581-2,638$ \\
\hline - Weighted average & 2,013 & 1,944 & 2,131 & 1,838 & 1,900 & 2,031 \\
\hline \multicolumn{7}{|l|}{ Diesel (kg/ha) } \\
\hline - Range & $0-8$ & $0-16$ & $8-16$ & $0-8$ & $0-16$ & $0-8$ \\
\hline - Weighted average & 8 & 10 & 16 & 1 & 9 & 8 \\
\hline \multicolumn{7}{|l|}{ Synthetic fertilizer $(\mathrm{kg} / \mathrm{ha})$} \\
\hline - Range & $6,275-26,894$ & $2,406-28,500$ & $10,781-14,150$ & $6,031-51,681$ & $1,488-27,763$ & $7,713-18,875$ \\
\hline - Weighted average & 13,381 & 13,525 & 13,044 & 13,613 & 10,681 & 13,238 \\
\hline \multicolumn{7}{|l|}{ Organic fertilizer $(\mathrm{kg} / \mathrm{ha})$} \\
\hline - Range & $0-13,088$ & $0-16,875$ & $0-4,375$ & $0-33,750$ & $0-12,719$ & 0 \\
\hline - Weighted average & 550 & 569 & 725 & 763 & 625 & 0 \\
\hline \multicolumn{7}{|l|}{ Chemicals (kg/ha) } \\
\hline - Range & $0-394$ & $0-781$ & $0-156$ & $0-394$ & $0-338$ & $0-406$ \\
\hline - Weighted average & 88 & 113 & 100 & 75 & 25 & 144 \\
\hline
\end{tabular}

The plantation inventory mainly concerned fertilizer application conducted in three stages as the cultivating stage, pre-tapping stage (1-7 years) and post-tapping stage (825 years). Both synthetic and organic fertilizers were used but synthetic fertilizer application tended to be higher than organic fertilizer. Average application of synthetic fertilizer ranged from 10,681-23,844 kg/ha and Udon Thani applied more synthetic fertilizer than the other provinces. Average application of organic fertilizer ranged from 0 to $37,150 \mathrm{~kg} / \mathrm{ha}$.

Two sources of GHG emissions were considered as fertilizer production and nitrogen-based fertilizer. GHG emissions from fertilizer production (defined here as indirect emissions) were estimated from the amount of chemical fertilizer used multiplied by emissions factors based on the Thailand database. GHG emissions from nitrogen-based fertilizers were estimated from the quantity of nitrogen added to the soil by using Equation 2. An amount of $0.01 \%$ of nitrogen was converted to $\mathrm{N}_{2} \mathrm{O}$ (defined here as direct emissions). Table 2 shows that levels of $\mathrm{N}$ from synthetic fertilizer applications were higher than from organic fertilizer. Total $\mathrm{N}$ fertilizer application rates ranged from 2,024 to $5,793 \mathrm{~kg} \mathrm{~N} / \mathrm{ha}$ (a factor of three) or 80.96 to $231.72 \mathrm{~kg} \mathrm{~N} / \mathrm{ha} / \mathrm{y}$. Comparison to the $\mathrm{N}$-fertilizer requirement of rubber plant in Nigeria and Thailand, the $\mathrm{N}$-fertilizer recommendation were $112 \mathrm{~kg} \mathrm{~N} / \mathrm{ha}$ for first year (Orimoloye et al., 2010) and $70 \mathrm{~kg} \mathrm{~N} / \mathrm{ha}$ (Jawjit et al., 2010), respectively. However, the fertilizer application depends on plant nutrient status in soil and plant of each area (Dumrongrak, 2010).

Diesel fuel consumption of vehicles for planting was estimated from cycles of vehicle usage with two sources of GHG emissions as diesel production (defined here as indirect emissions) and fuel combustion (defined here as direct emissions).

Together with the allocations mentioned above, fertilizer application, diesel fuel consumption and pesticide use allocated to co-products like rubber wood and rubber waste were all considered in the summary of GHG emissions from fresh latex production .GHG emissions of fresh latex after the allocation were between 55.6$168.9 \mathrm{~g} \mathrm{CO}_{2}$-eq $/ \mathrm{kg}$ fresh latex (Table 3). The weighted average of small farms was $93 \mathrm{~g}$ $\mathrm{CO}_{2}$-eq/kg fresh latex, medium farms $94 \mathrm{~g} \mathrm{CO}_{2}-\mathrm{eq} / \mathrm{kg}$ fresh latex and large farms $98 \mathrm{~g}$ 
$\mathrm{CO}_{2}$-eq $/ \mathrm{kg}$ fresh latex, with total weighted average $95.26 \mathrm{~g} \mathrm{CO}_{2}$-eq $/ \mathrm{kg}$ fresh latex. The GHG emissions were quite similar and did not depend on farm size . The greatest contribution was from fertilizer application (both synthetic and organic) at more than 90\%. GHG emissions from diesel fuel and pesticide were lower compared to fertilizer (Table 4). The average GHG emissions from fertilizer was $91.34 \mathrm{~g} \mathrm{CO}_{2}$-eq $/ \mathrm{kg}$ fresh latex, which closed to $89.40 \mathrm{~g} \mathrm{CO}_{2}$-eq/ $/ \mathrm{kg}$ fresh latex (Soratana et al., 2017). The average distance of plant material delivery was $50 \mathrm{~km}$ and the GHG emission from delivery was less than $1 \mathrm{~g} \mathrm{CO}_{2}$-eq/kg fresh latex. Besides fertilizer application, yield is one of the GHG emission factors. Average global fresh latex production is $1,194 \mathrm{~kg} / \mathrm{ha}$ (FAOSTAT, 2017). In this study, the yield was about 1.4-2.7 times higher than the global average. Factors for GHG emission include both $\mathrm{N}$ fertilizer application and yield. Fertilizer application was applied varies from farm to farm and did not reflect increased yields. The different rate of fertilizer application is not clear even the same clone and cultivation area, which is the same discussion as Yuttitham et al. (2011) studied on the GHG emission of sugarcane in Thailand. However, there are recommendation of optimum level of fertilizer application based on soil condition, by Department of Agriculture, Thai farmer usually apply fertilizer more than that level. The excess amount not only unaffect to yield, but also sometime decrease the productivity. Therefore, from this study the proportional of yield and amount of fertilizer applied is absent.

Table 2. Use of fertilizers

\begin{tabular}{|c|c|c|c|c|c|c|c|c|c|}
\hline \multirow{2}{*}{ Fertilizer } & \multicolumn{3}{|c|}{$\begin{array}{l}\text { Chanthaburi } \\
\text { Farm size }\end{array}$} & \multicolumn{3}{|c|}{$\begin{array}{l}\text { Rayong } \\
\text { Farm size }\end{array}$} & \multicolumn{3}{|c|}{$\begin{array}{l}\text { Bueng Kan } \\
\text { Farm size }\end{array}$} \\
\hline & Small & Medium & Large & Small & Medium & Large & Small & Medium & Large \\
\hline \multicolumn{10}{|l|}{ Synthetic (ha/kg) } \\
\hline$-N$ & 2,322 & 2,976 & 2,132 & 1,903 & 1,958 & 3,119 & 2,463 & 3,363 & 3,878 \\
\hline$-\mathrm{P}$ & 1,557 & 1,385 & 1,419 & 1,108 & 1,215 & 744 & 1,327 & 1,285 & 1,828 \\
\hline$-\mathrm{K}$ & 2,701 & 2,081 & 1,774 & 1,923 & 1,933 & 2,525 & 2,226 & 2,734 & 4,446 \\
\hline \multicolumn{10}{|l|}{ Organic (kg/ha) } \\
\hline$-\mathrm{N}$ & 61 & 144 & - & 405 & 85 & - & 111 & 82 & 496 \\
\hline$-\mathrm{P}$ & 51 & 85 & - & 174 & 46 & - & 64 & 78 & 617 \\
\hline$-\mathrm{K}$ & 35 & 84 & - & 207 & 39 & - & 65 & 48 & 375 \\
\hline \multirow[t]{2}{*}{ Fertilizer } & \multicolumn{3}{|c|}{$\begin{array}{l}\text { Udon Thani } \\
\text { Farm size }\end{array}$} & \multicolumn{3}{|c|}{$\begin{array}{l}\text { Nakhon Si Thammarat } \\
\text { Farm size } \\
\end{array}$} & \multicolumn{3}{|c|}{$\begin{array}{l}\text { Suratthani } \\
\text { Farm size }\end{array}$} \\
\hline & Small & Medium & Large & Small & Medium & Large & Small & Medium & Large \\
\hline \multicolumn{10}{|l|}{ Synthetic (kg/ha) } \\
\hline$-N$ & 3,281 & 4,697 & 5,793 & 2,248 & 2,484 & 2,171 & 2,399 & 2,063 & 2,685 \\
\hline - P & 1,637 & 4,335 & 1,208 & 1,329 & 1,371 & 1,016 & 1,435 & 1,077 & 1,334 \\
\hline - K & 2,706 & 4,359 & 3,476 & 1,992 & 2,122 & 1,782 & 1,997 & 1,498 & 1,818 \\
\hline \multicolumn{10}{|l|}{ Organic (kg/ha) } \\
\hline$-\mathrm{N}$ & 86. & 27 & - & 10 & 15 & 13 & 24.31 & 10.88 & - \\
\hline$-\mathrm{P}$ & 63 & 25 & - & 9 & 10 & 12 & 14.44 & 10.31 & - \\
\hline - K & 50 & 15 & - & 6 & 9 & 7 & 14.25 & 6.31 & - \\
\hline
\end{tabular}


Table 3. GHG emissions of latex cultivation process ( $\mathrm{g} \mathrm{CO}_{2}$-eq/kg fresh latex)

\begin{tabular}{|c|c|c|c|c|c|c|c|c|c|}
\hline \multirow[t]{2}{*}{ Cultivation stage } & \multicolumn{3}{|c|}{$\begin{array}{c}\text { Chanthaburi } \\
\text { Farm size }\end{array}$} & \multicolumn{3}{|c|}{$\begin{array}{c}\text { Rayong } \\
\text { Farm size }\end{array}$} & \multicolumn{3}{|c|}{$\begin{array}{l}\text { Bueng Kan } \\
\text { Farm size }\end{array}$} \\
\hline & Small & Medium & Large & Small & Medium & Large & Small & Medium & Large \\
\hline & 0.16 & & 0.13 & 0.16 & 0.18 & 0.41 & 0.35 & 0.30 & 0.29 \\
\hline Before tapping & 18.80 & 18.90 & 13.70 & 16.10 & 13.70 & 18.90 & 21.00 & 21.80 & 30.60 \\
\hline During tapping & 69.70 & 74.60 & 41.80 & 51.20 & 46.00 & 61.80 & 73.70 & 90.20 & 92.40 \\
\hline Total & 88.66 & 93.61 & 55.63 & 67.46 & 59.88 & 81.11 & 95.05 & 112.30 & 126.29 \\
\hline \multirow[t]{2}{*}{ Cultivation stage } & \multicolumn{3}{|c|}{$\begin{array}{c}\text { Udon Thani } \\
\text { Farm size }\end{array}$} & \multicolumn{3}{|c|}{$\begin{array}{c}\text { Nakhon Si Thammarat } \\
\text { Farm size }\end{array}$} & \multicolumn{3}{|c|}{$\begin{array}{l}\text { Suratthani } \\
\text { Farm size }\end{array}$} \\
\hline & Small & Medium & Large & Small & Medium & Large & Small & Medium & Large \\
\hline Pre farming & 0.28 & 0.25 & 0.32 & 0.19 & 0.29 & 0.31 & 0.07 & 0.21 & 0.14 \\
\hline Before tapping & 30.10 & 27.70 & 28.40 & 20.10 & 23.20 & 18.20 & 20.40 & 17.00 & 14.80 \\
\hline During tapping & 101.30 & 86.20 & 140.20 & 71.20 & 90.00 & 68.50 & 73.60 & 57.40 & 70.80 \\
\hline Total & 131.68 & 114.15 & 168.92 & 91.49 & 113.49 & 87.01 & 94.07 & 74.61 & 85.74 \\
\hline
\end{tabular}

Table 4. GHG emissions from fertilizer, diesel and herbicide and insecticide ( $\mathrm{g} \mathrm{CO}_{2}$-eq/kg fresh latex)

\begin{tabular}{|c|c|c|c|c|c|c|c|c|c|}
\hline & \multicolumn{3}{|c|}{$\begin{array}{c}\text { Chanthaburi province } \\
\text { Farm size }\end{array}$} & \multicolumn{3}{|c|}{$\begin{array}{l}\text { Rayong } \\
\text { Farm size }\end{array}$} & \multicolumn{3}{|c|}{$\begin{array}{l}\text { Bueng Kan } \\
\text { Farm size }\end{array}$} \\
\hline & Small & Medium & Large & Small & Medium & Large & Small & Medium & Large \\
\hline GHG from fertilizer & & & & & & & & & \\
\hline Direct emission & 32.60 & 40.60 & 21.50 & 26.90 & 23.10 & 36.70 & 37.60 & 47.00 & 46.50 \\
\hline Indirect emission & 54.00 & 51.10 & 30.60 & 39.10 & 34.90 & 43.90 & 53.60 & 61.80 & 73.70 \\
\hline GHG from diesel & & & & & & & & & \\
\hline Direct emission & 0.00 & 0.00 & 0.10 & 0.10 & 0.10 & 0.10 & 0.20 & 0.20 & 0.20 \\
\hline Indirect emission & 0.00 & 0.00 & $<0.10$ & $<0.10$ & $<0.10$ & $<0.10$ & $<0.10$ & $<0.10$ & $<0.10$ \\
\hline \multirow[t]{3}{*}{$\begin{array}{l}\text { GHG from herbicide } \\
\text { and insecticide }\end{array}$} & 2.10 & 1.90 & 3.40 & 1.40 & 1.80 & 0.40 & 3.70 & 3.30 & 5.90 \\
\hline & \multicolumn{3}{|c|}{$\begin{array}{l}\text { Udon Thani province } \\
\text { Farm size }\end{array}$} & \multicolumn{3}{|c|}{$\begin{array}{c}\text { Nakhon Si Thammarat } \\
\text { Farm size }\end{array}$} & \multicolumn{3}{|c|}{$\begin{array}{l}\text { Suratthani } \\
\text { Farm size }\end{array}$} \\
\hline & Small & Medium & Large & Small & Medium & Large & Small & Medium & Large \\
\hline \multicolumn{10}{|l|}{ GHG from fertilizer } \\
\hline Direct emission & 53.70 & 62.70 & 76.70 & 35.50 & 45.00 & 34.60 & 37.60 & 30.80 & 34.90 \\
\hline Indirect emission & 73.10 & 46.40 & 84.40 & 51.10 & 63.10 & 46.60 & 52.70 & 40.00 & 43.90 \\
\hline \multicolumn{10}{|l|}{ GHG from diesel } \\
\hline Direct emission & 0.20 & 0.20 & 0.20 & 0.00 & 0.10 & 0.20 & 0.00 & 0.00 & 0.00 \\
\hline Indirect emission & $<0.10$ & $<0.10$ & $<0.10$ & 0.00 & $<0.10$ & $<0.10$ & 0.00 & 0.00 & 0.00 \\
\hline $\begin{array}{l}\text { GHG from herbicide } \\
\text { and insecticide }\end{array}$ & 4.70 & 4.90 & 7.60 & 4.90 & 5.30 & 5.60 & 3.80 & 3.80 & 6.90 \\
\hline
\end{tabular}


Results were compared with findings by Jawjit et al. (2010) GHG emissions of rubber plantations in Thailand, with yield estimated at 5.64 tons of fresh latex per ha/year. GHG emissions were estimated at 0.2 tons $\mathrm{CO}_{2}$-eq/ton fresh latex, which was almost twice the average found here .The difference probably results from the fact that they did not allocate fresh latex and rubber wood; therefore, it is possible that the study was performed without any allocations. If assume that both studies used the same ratio, then GHG emissions in Jawjit et al. (2010) study would be $70 \mathrm{~g} \mathrm{CO}_{2}$-eq/kg fresh latex which was similar to findings.

\section{Greenhouse gas emissions of concentrated latex production}

Primary data were collected from three concentrated latex factories through observations and on-site interviews. All of those factories are located in the south. The annual average production of those factories were in range of 13-18 million kilograms. The questionnaire began with the production process, yield, and amount of materials such as fresh latex, ammonia, water and chemicals including electric energy and fuel consumption (Table 5). Data were derived from DRC allocation between the chosen products, scrap and skim latex which ranged from $80-90 \%$. Table 5 shows the capacity of concentrated high ammonia (HA) latex production at 21,000 ton/y. One ton of concentrated latex production required 1.95-2.31 tons of fresh latex, lower than recorded by Jawjit et al. (2015) at 2.5 tons. Main factors related to production are electricity, water and chemicals. Electricity consumption in each plant was 41.19-77.84 $\mathrm{kWh} /$ ton concentrated latex and the centrifuge process required the greatest amount of electricity accounting for $94-97 \%$ of total consumption .Water use in concentrated latex ranged from 1,999-4,715 L. Most water was required for the centrifuge process and used for cleaning the centrifugal machines and tanks at $43-92 \%$ of total water use. Water was used for preparing materials in plant A more than plants B and C. The use of ammonia ranged from $15.7-14.9 \mathrm{~kg} /$ ton concentrated latex.

Table 5. Some inventory data collected from three concentrated latex factories

\begin{tabular}{c|c|c|c|c|c}
\hline Activities data & Unit & Factory A & Factory B & Factory C & $\begin{array}{c}\text { Weighted } \\
\text { average }\end{array}$ \\
\hline Fresh latex & $\mathrm{kg}$ & 2070 & 1950 & 2310 & 2085.47 \\
Electricity & $\mathrm{kWh}$ & 52.61 & 41.19 & 77.59 & 55.30 \\
Diesel & $\mathrm{kg}$ & 0.17 & 0.66 & 0.13 & 0.30 \\
Water & $\mathrm{kg}$ & 3489.07 & 1999.98 & 4715.15 & 3322.56 \\
Ammonia & $\mathrm{kg}$ & 15.42 & 15.70 & 14.9 & 15.39 \\
Tetramethyl thiuram disulfide (TMTD) & $\mathrm{kg}$ & 0.58 & 0.46 & 0.81 & 0.59 \\
Zinc oxide (ZnO) & $\mathrm{kg}$ & 0.58 & 0.46 & 0.81 & 0.59 \\
Diammonium hydrogen phosphate (DAP) & $\mathrm{kg}$ & 1.80 & 1.59 & 2.18 & 1.82 \\
Lauric acid & $\mathrm{kg}$ & 0.58 & 0.45 & 0.82 & 0.59 \\
\hline
\end{tabular}

Unit: amounts per 1 ton of concentrated latex produced

Gate-to-gate GHG emissions were calculated for in materials delivery, fresh latex preparation, the centrifuge process and fresh latex preservation. Results showed that GHG emissions from the production process were 88.73-100.73 $\mathrm{kg} \mathrm{CO}_{2}$-eq/ton 
concentrated latex (Table 6). The highest GHG emissions were from chemical production accounting for $43-54 \%$. Ammonia contributed $36-46 \%$ of GHG emission, while energy use (both diesel and electricity) was responsible for 32-39\%. Remaining usage was from waster production and wastewater treatment at about $9-17 \%$, with the highest as from the centrifuge process $(27-43 \%)$. After calculating the weighted average of concentrated latex production, GHG emissions were equivalent to $92.74 \mathrm{~kg} \mathrm{CO}_{2}$ eq/ton concentrated latex. Jawjit et al. (2010) analyzed Thailand's GHG emissions at $144 \mathrm{~kg} \mathrm{CO}$-eq/ton concentrated latex with hotspots mainly dependent on electricity and ammonia use.

Table 6. GHG emissions of the production of 1 ton concentrated latex ( $\mathrm{kg} \mathrm{CO}_{2}-\mathrm{eq}$ )

\begin{tabular}{|c|c|c|c|c|c|c|c|c|c|c|c|}
\hline \multirow[t]{2}{*}{ Factory } & \multirow[t]{2}{*}{ Total } & \multicolumn{2}{|c|}{$\begin{array}{c}\text { Production } \\
\text { and use of } \\
\text { energy }\end{array}$} & \multicolumn{6}{|c|}{ Production of chemicals } & \multicolumn{2}{|c|}{ Others } \\
\hline & & [1] & [2] & [3] & [4] & [5] & {$[6]$} & [7] & [8] & [9] & [10] \\
\hline Factory A & 91.73 & 28.79 & 0.57 & 39.17 & 1.45 & 1.46 & 4.50 & 0.23 & 0.02 & 0.44 & 15.10 \\
\hline Factory B & 88.76 & 22.73 & 10.54 & 40.83 & 1.18 & 1.19 & 4.13 & 0.18 & 0.00 & 0.68 & 7.30 \\
\hline Factory C & 100.73 & 39.21 & 0.48 & 36.18 & 1.92 & 1.87 & 2.80 & 0.31 & 0.36 & 0.00 & 17.60 \\
\hline Weighted Average & 92.74 & 29.22 & 3.35 & 39.02 & 1.47 & 1.48 & 4.05 & 0.23 & 0.08 & 0.42 & 13.43 \\
\hline
\end{tabular}

Remark: [1]: Electricity, [2]: Diesel, [3]: Ammonia, [4]: TMTD, [5]: ZnO, [6]: DAP, [7]: Lauric acid, [8]: Other chemicals, [9]: Water, [10]: Wastewater

When considering cradle-to-gate GHG emissions beginning with growing rubber trees in section 3.1 and concentrated latex production as mentioned above, total GHG emissions were $291.40 \mathrm{~kg} \mathrm{CO}$-eq/ton concentrate latex. Cultivation was highest contributor to GHG emissions at $68 \%$. In more detail, production and use of fertilizer were highest sources of GHG emissions and accounted for $60 \%$, while electricity and diesel fuel accounted for $10 \%$, with chemicals accounting for $15 \%$. In comparison, Jawjit et al. (2010) calculated GHG emissions at 0.54 tons $\mathrm{CO}_{2}$-eq/ton concentrated latex, almost $50 \%$ lower than our calculated impacts. The difference can be explained by the allocation of para cultivation. Jawjit et al. (2010) did not refer to the allocation or the proportion of fresh latex and rubber wood, including the allocation method in the concentrated latex production. If co-product allocation is not taken into account and environmental load of the product not reduced, then the environmental impact may be artificially increased.

\section{Greenhouse gas emissions of rubber glove production}

Primary data were conducted through on-site interviews with one participating latex glove industry which located in the southern part of Thailand. One hundred pairs of rubber gloves (set as the functional unit) were manufactured; however, an overview of GHG emissions was presented here, since inventory data were confidential company information. GHG emission of rubber glove production was considered by a gate-tograve approach with a functional unit. Manufacturing 100 pairs of rubber gloves required $5 \mathrm{~kg}$ concentrated latex and their GHG emission was estimated at $42.06 \mathrm{~kg}$ $\mathrm{CO}_{2}$-eq/100 pairs. As shown in Figure 2, \%GHG emissions contribution implied that 
packaging and used gloves disposal contributed $46 \%$ and $93 \%$ of that was from burning the gloves (estimated under Thailand Product Categories Rule of rubber gloves describing that rubber gloves for medical use must be burnt after use), with $37 \%$ from the energy sector as electricity and fuel divided into two parts as the dipping and drying process $(55 \%)$ and chemical production (10\%).

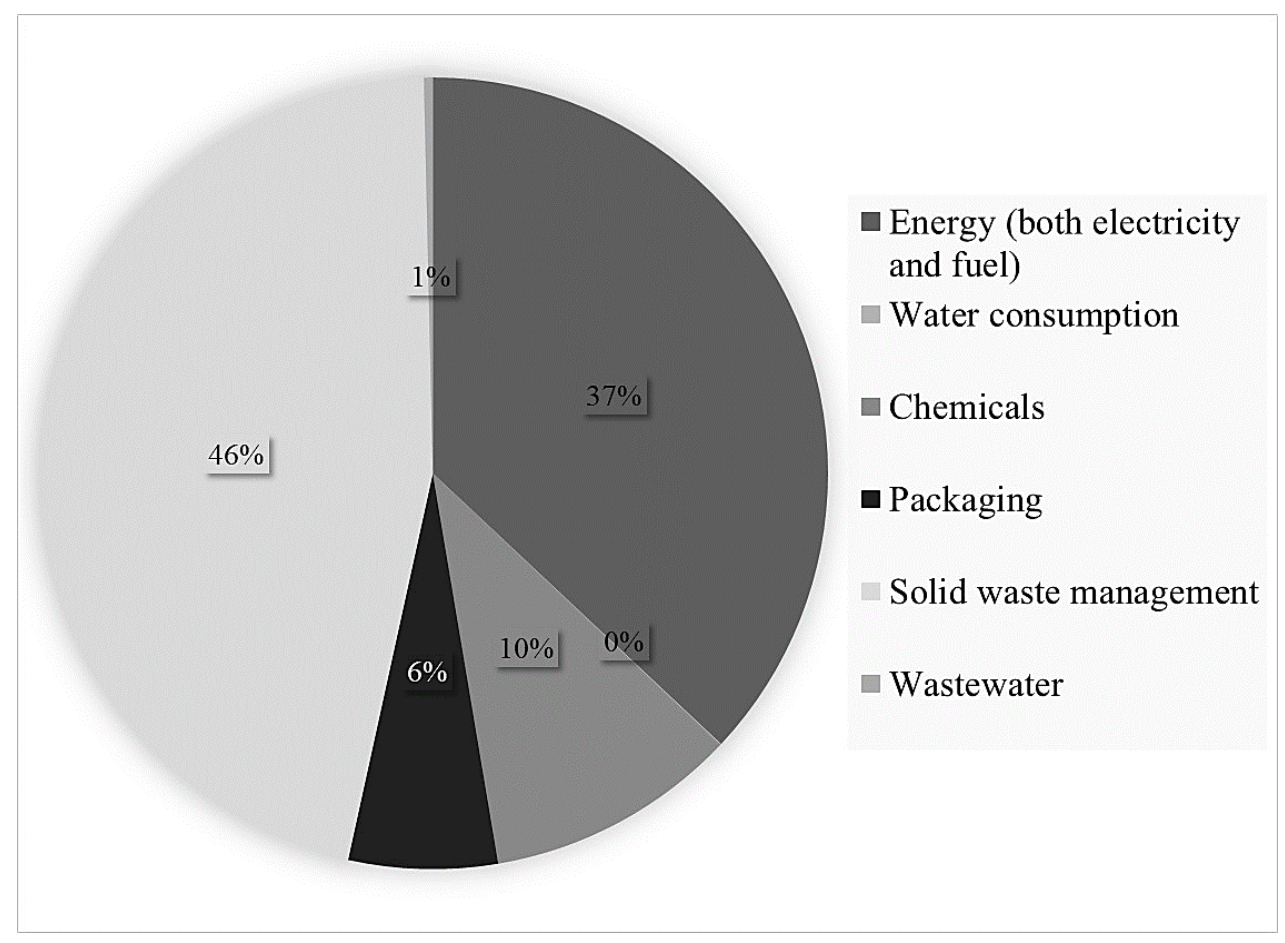

Figure 2. GHG emission percentage contribution of rubber glove production

The overall results obtained were based on the final functional unit (product of 200 pieces large size rubber gloves). Overall $\mathrm{GHG}$ emissions were $42.07 \mathrm{~kg} \mathrm{CO}$-eq, considered as cradle-to-grave. To facilitate the analysis, disaggregating GHG emissions results were divided according to each phase. Figure 3 presents a clear understanding of the different points of each process. Considering only the planting process, fertilizer application was the main contributor to GHG emissions, while harvesting natural latex was the largest emission source when focusing on concentrated latex. Meanwhile, glove processing was the most crucial contributor to global warming impact at 52\%, following by solid waste management at $46 \%$. Production of fresh and concentrated latex gave less than $1 \%$ contribution.

\section{Effect of allocation on the carbon footprint of rubber gloves}

Determining the appropriate allocation model from the results above (base scenario) was divided into planting process based on mass-based allocation of fresh latex and rubber wood, concentrated latex production based on DRC allocation of concentrated latex and skim latex and rubber glove production based on mass-based allocation .The effects of different allocation methods were studied by defining the following scenarios: scenario 1 was economic allocation in the planting process and DRC allocation in concentrated latex production, scenario 2 was mass allocation in the planting process 
and mass allocation in concentrated latex production and scenario 3 was economic allocation in the planting process and mass allocation in concentrated latex production (Table 7).

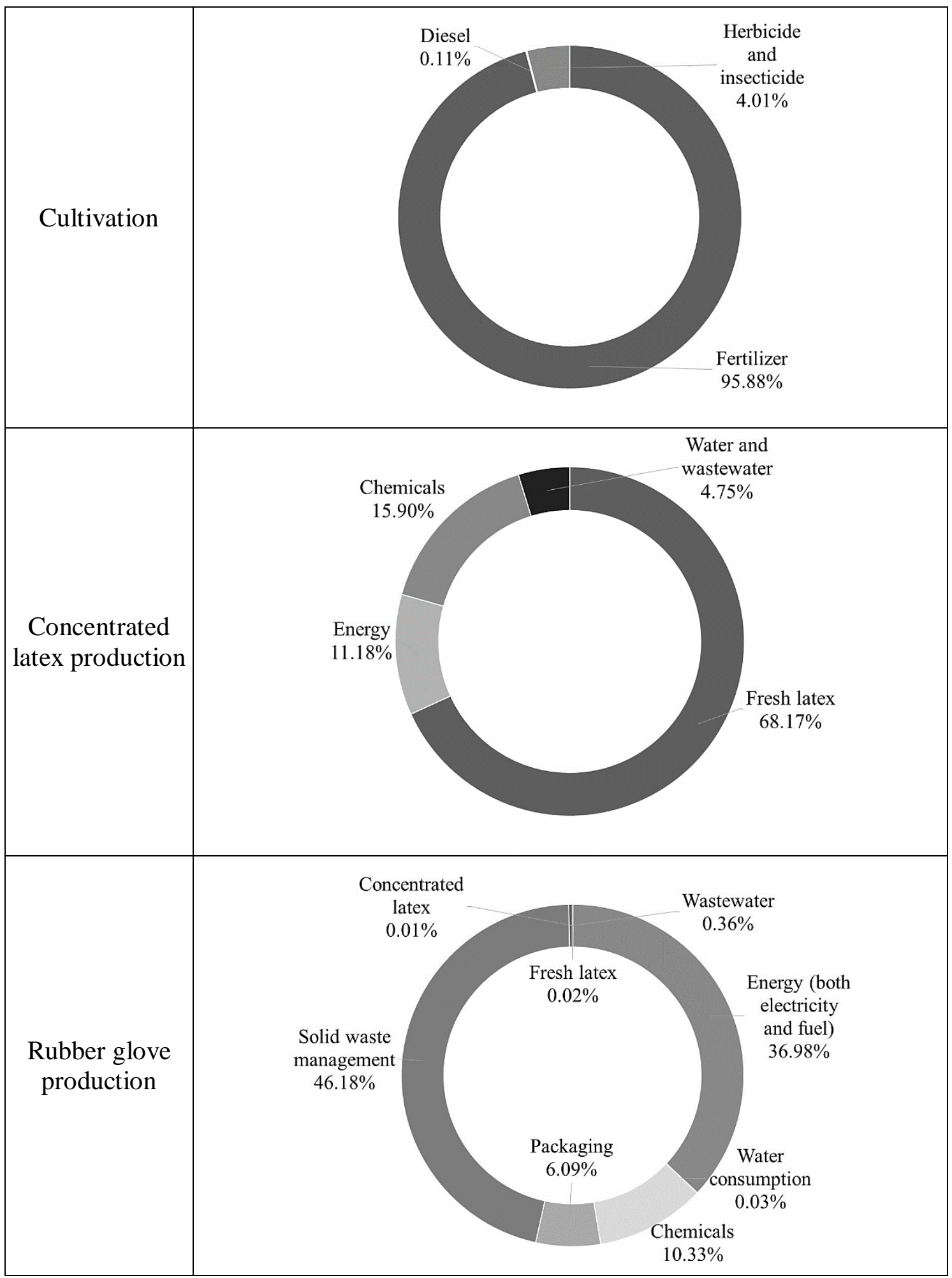

Figure 3. Carbon footprint contribution results disaggregated by the rubber glove production chain 
Table 7. Allocation method for each scenario

\begin{tabular}{c|c|c|c}
\hline & Cultivation & $\begin{array}{c}\text { Concentrated latex } \\
\text { production }\end{array}$ & $\begin{array}{c}\text { Rubber glove } \\
\text { production }\end{array}$ \\
\hline Base scenario & Mass allocation & DRC allocation & Mass allocation \\
Scenario 1 & Economic allocation & DRC allocation & Mass allocation \\
Scenario 2 & Mass allocation & Mass allocation & Mass allocation \\
Scenario 3 & Economic allocation & Mass allocation & Mass allocation \\
\hline
\end{tabular}

Considering the economic allocation in the planting process determined that prices of fresh latex fluctuated over time. The average price over the past three years was 1.47 USD per kilogram ( $\sim 34$ Baht per 1 USD) (Rubber Authority of Thailand, 2016). Price of rubber waste is similar to or $15 \%$ lower than fresh latex, while the average price of 10-inch rubber wood is about 0.067 USD per kilogram (Rubber Authority of Thailand, 2012). Therefore, the average percentage allocation of fresh latex accounted for $91 \%$. When considering mass allocation in concentrated latex production, the amount of latex concentrated by centrifuge machinery accounted for approximately $43 \%$. After applying mass allocation, GHG emissions from concentrated latex decreased when compared to the base scenario.

Table 8 presents two methods of allocation which led to totally different results when focusing only on the planting process. Economic allocation resulted in fresh latex providing more environmental load than rubber wood; GHG emissions became higher and percentage change was equivalent to 152.16 . When focusing on concentrated latex as an intermediate product, different allocation methods led to a percentage change of 48.78 to $14.26 \%$; however, when focusing on the final product (rubber glove), percentage change became less $(-0.017$ to 0.005$)$ with no significant difference .Thus, it was very important to consider GHG emissions of rubber wood products and allocation during the upstream process became less when the supply chain length increased.

Table 8. Comparison of GHG emission for different scenarios of allocation methods

\begin{tabular}{c|c|c|c|c|c|c}
\hline & \multicolumn{2}{|c|}{ Cultivation } & \multicolumn{2}{c|}{ Concentrated latex production } & \multicolumn{2}{c}{ Rubber glove production } \\
\cline { 2 - 7 } & $\begin{array}{c}\text { g CO2-eq/kg } \\
\text { fresh latex }\end{array}$ & \% change & $\begin{array}{c}\text { kg CO} \text {-eq/ton } \\
\text { concentrated latex }\end{array}$ & \%change & $\begin{array}{c}\text { kg CO } \text {-eq/200 } \\
\text { pieces }\end{array}$ & \% change \\
\hline Base scenario & 95.26 & & 291.40 & & 42.07 & \\
Scenario 1 & 240.20 & +152.16 & 332.94 & +14.26 & 42.08 & $0.0+1$ \\
Scenario 2 & 95.26 & 0 & 149.26 & -48.78 & 42.07 & $0.0-2$ \\
Scenario 3 & 240.20 & +152.16 & 294.20 & +0.96 & 42.07 & +0.00 \\
\hline
\end{tabular}

Scenario 1 = economic, DRC; Scenario 2 = mass, mass; Scenario 3 = economic, mass

\section{Conclusion}

Rubber and rubber products are used globally. A cradle-to-gate GHG emission assessment was carried out through an LCA perspective for fresh latex cultivation, concentrated latex production, and a cradle-to-graves GHG emission assessment for rubber gloves production. The main purpose was to evaluate and identify hotspots of these productions. 
Results gave $95.26 \mathrm{~g} \mathrm{CO}_{2}$-eq/kg fresh latex. Farm size was not an obvious indicator of farm management performance and hotspots were mainly from fertilizers, accounting for $96 \%$. Average GHG emission from concentrated latex was $291.40 \mathrm{~kg} \mathrm{CO}$-eq/ton concentrate latex, with hotspots from utilization of fertilizers in fresh latex production, accounting for $68 \%$. GHG emissions from rubber gloves was $42.07 \mathrm{~kg} \mathrm{CO}_{2}$-eq/200 pieces of rubber glove with hotspots from burning wastes and glove production generated by electric power accounting for $83 \%$.

Other allocation methods differed for economic and mass allocation at each stage of the product life cycle. Allocation had a great impact on GHG emissions during cultivation and processing of concentrated latex but little effect on rubber glove production. Defining the allocation method for rubber products has a huge effect on GHG emissions in the upstream processes and these effects are reduced when supply chains become longer.

Acknowledgements. This research was partially supported by The Thailand Research Fund (TRF): RDG5750105 and RDG5850113.

\section{REFERENCES}

[1] Abeliotis, K., Detsis, V., Papia, C. (2013): Life cycle assessment of bean production in the Prespa National Park, Greece. - Journal of Cleaner Production 41: 89-96.

[2] Adewale, C., Higgins, S., Granatstein, D., Stockle, C. O., Carlson, B. R., Zaher, U. E., Carpenter-Boggs, L. (2016): Identifying hotspots in the carbon footprint of a small scale organic vegetable farm. - Agricultural Systems 149: 112-121.

[3] Choosong, T., Chomanee, J., Tekasakul, P., Tekasakul, S., Otani, Y., Hata, M., Furuuchi, M (2010): Workplace environment and personal exposure of PM and PAHs to workers in natural rubber sheet factories contaminated by wood burning smoke. - Aerosol and Air Quality Research 10: 8-21.

[4] Dayaratne, S. P., Gunawardana, K. D. (2015): Carbon footprint reduction :a critical study of rubber production in small and medium scale enterprises in Sri Lanka. - Journal of Cleaner Production 103: 87-103.

[5] Dumrongrak, I. (2010): Fertilizer management for sustainable rubber plantation. Journal of Yala Rajabhat University 5(2): 183-199.

[6] Ecoinvent Centre (2010): Ecoinvent database ver2.2 categories for processes. - Ecoinvent Centre. Swiss Centre for Life Cycle Inventories. Zurich. Switzerland.

[7] FAOSTAT (2017): Food and Agriculture Organization of the United Nations. http//:www.fao.org/faostat/en/\#data. Accessed January 2017.

[8] Fichedick, M., Roy, J., Abdel-Aziz, A., Acquaye, A., Allwood, J. M., Ceron, J. P., Geng, Y., Kheshgi, H., Lanza, A., Perczyk, D., Price, L., Santalla, E., Sheinbaum, C., Tanaka, K. (2014): Industry. - In: Metz, B., Davidson, O. R., Bosch, P. R., Dave, R., Meyer, L. A. (eds.) Climate Change 2014: Mitigation of Climate Change. Contribution of Working Group III to the Fifth Assessment Report of the Intergovernment Panel on Climate Change. Cambridge University Press, Cambridge, UK and New York, USA.

[9] Holka, M., Jankowiak, J., Bienkowski, J. F., Dabrowicz, R. (2016): Life cycle assessment (LCA) of winter wheat in an intensive crop production system in Wielkopolska region (Poland). - Applied Ecology and Environmental Research 14(3): 535-545.

[10] ISO14040 (2006): International Organization for Standardization, ISO14040:2006 Environmental Management-Life Cycle Assessment-Principles and Framework. - ISO, Geneva, Switzerland. 
[11] ISO14044 (2006): International Organization for Standardization, ISO14044:2006 Environmental Management-Life Cycle Assessment-Requirements and Guidelines. ISO, Geneva, Switzerland.

[12] ISO/TS14067 (2013): International Organization for Standardization, ISO/TS14067 Greenhouse Gases-Carbon Footprint of Products-Requirements and Guidelines for Quantification and Communication. - ISO, Geneva, Switzerland.

[13] Jawjit, W., Kroeze, C., Rattanapan, S. (2010): Greenhouse gas emissions from rubber industry in Thailand. - Journal of Cleaner Production 18: 403-411.

[14] Jawjit, W., Pavasant, P., Kroeze, C. (2015): Evaluating environmental performance of concentrated latex production in Thailand. - Journal of Cleaner Production 98: 84-91.

[15] Kabiri, N. (2016): Public participation, land use and climate change governance in Thailand. - Land Use Policy 52: 511-517.

[16] Lin, T. H., Chien, Y. S., Chiu, W. M. (2017): Rubber tire life cycle assessment and the effect of reducing carbon footprint by replacing carbon black with graphene. International Journal of Green Energy 14(1): 97-104.

[17] Maulina, S., Sulaiman, N. M. N., Mahmood, N. Z. (2015): Enhancement of ecoefficiency through life cycle assessment in crumb rubber processing. - Procedia Social and Behavioral Sciences 195: 2475-2484.

[18] Meier, M. S., Stoessel, F., Jungbluth, N., Juraske, R., Schader, C., Stolze, M. (2015): Environmental impacts of organic and conventional agricultural products-Are the differences captured by life cycle assessment? - Journal of Environmental Management 149: 193-208.

[19] Mohammad, M., Che-man, H., Hassan, M. A., Yee, P. L. (2010): Treatment of wastewater from rubber industry in Malaysia. - African Journal of Biotechnology 9(38): 6233-6243.

[20] Musikavong, C., Gheewala, S. H (2017): Assessing ecological footprints of products from the rubber industry and palm oil mills in Thailand. - Journal of Cleaner Production 142: $1148-1157$.

[21] National Metal and Materials Technology Center (2014): Thai National Life Cycle Inventory Database. - MTEC, Pathum Thani, Thailand.

[22] OAE (2016a): Office of Agricultural Economics, Agricultural Statistic of Thailand. http//:www.oae.go.th/ewt_news.php?nid=13577. Accessed January 2017.

[23] OAE (2016b): Office of Agricultural Economics. Ministry of Agriculture and Cooperatives. - http://www.oae.go.th/download/forecast/forecastofmarch59.pdf. Accessed January 2017.

[24] OIE (2014): Office of Industrial Economics. - http://rubber.oie.go.th. Accessed January 2017.

[25] Orimoloye, J.R., Ugwa, I.K., Idoko, S.O. (2010): Soil management strategies for rubber cultivation in an undulating topography of Northern Cross River State. - Journal of Soil Science and Environmental Management 1(2): 34-39.

[26] Ounsaneha, W., Rattanapan, C. (2016): Defining the eco-efficiency of rubber glove products manufactured from concentrated latex in Thailand. - Environmental Progress \& Sustainable Energy 35(3): 802-808.

[27] Pethin, D., Nakkanong, K., Nualsri, C. (2015): Performance and genetic assessment of rubber tree clones in Southern Thailand. - Scientia Agricola 72(4): 306-313.

[28] Phungrassami, H., Usubharatana, P. (2015): Life cycle assessment and eco-efficiency of para-rubber wood production in Thailand. - Polish Journal of Environmental Studies 24(5): 2113-2126.

[29] RIU (2017): Rubber Intelligence Unit, Office of Industrial Economics, Natural Rubber Export Statistic. - http//:rubber.oir.go.th. Accessed January 2017. 
[30] Ruangsri, K., Makkaew, K., Sdoodee, S. (2015): The impact of rainfall fluctuation on days and rubber productivity in Songkhla province. - International Journal of Agricultural Technology 11(1): 181-191.

[31] Rubber Authority of Thailand (2012): Price of parawood. http//:www.rubber.co.th/rubber2012/web/service9.php. Accessed March 2017.

[32] Rubber Authority of Thailand (2016): Price of latex and rubber product. http//:www.rubber.co.th/rubber/2012rubberprice_yr.php. Accessed March 2017.

[33] Rubber Replanting Aid Fund Act (1960): Rubber Replanting Aid Fund Act B.E. 2503. 1960. - http://www.raot.co.th/raot_en/ewt_w3c/ewt_dl_link.php?nid=1184. Accessed Febuary 2017.

[34] Sdoodee, S., Rongsawat, S. (2012): Impact of climate change on smallholders' rubber production in Songkhla province, Southern Thailand. - The 2012 International and National Conference for the Sustainable Community Development of "Local Community: The Foundation of Development in the ASEAN Economic Community (AEC)" February 16-19, 2012, Khon Kaen, Thailand.

[35] Solomon, S., Qin, D., Manning, M., Chen, Z., Marquis, M., Averyt, K. B., Tignor, M., Miller, H. L. (eds.) (2007): Intergovernmental Panel on Climate Change (IPCC). Climate Change 2007: The Physical Basis. Contribution of Working Group I to the Fourth Assessment Report of the Intergovernmental Panel on Climate Change. - Cambridge University Press, Cambridge, UK and New York.

[36] Soratana, K., Rasutis, D., Azarabadi, H., Eranki, P. L., Landis, A. E. (2017): Guayule as an alternative source of natural rubber: a comparative life cycle assessment with Hevea and synthetic rubber. - Journal of Cleaner Production 159: 271-280.

[37] Sparrevik, M., Field, J. L., Maratinsen, V., Breedveld, G. D., Cornelissen, G. (2015): Life cycle assessment to evaluate the environmental impact of biochar implementation in conservation agriculture in Zambia. - Environmental Science \& Technology 47: 12061215.

[38] Wang, M., Xia, X., Zhang, Q., Liu, L. (2010): Life cycle assessment of a rice production system in Taihu region, China. - International Journal of Sustainable Development \& World Ecology 17(2): 157-161.

[39] Yan, M., Cheng, K., Lue, T., Yan, Y., Pan, G., Rees, R. M. (2015): Carbon footprint of grain crop production in China-based on farm survey data. - Journal of Cleaner Production 104: 130-138.

[40] Yuttitham, M., Gheewala, S. H., Chidthaisong, A. (2011): Carbon footprint of sugar produced from sugarcane in eastern Thailand. - Journal of Cleaner Production 19(17-18): 2119-2127. 